\title{
Непрерывные и импульсные мощные полупроводниковые лазеры ближнего ИК диапазона
}

\section{Пихтин Н.А.}

ФТИ им. А.Ф. Иоффе, Политехническая, 26, Санкт-Петербург, 194021, Россия

DOI 10.34077/Semicond2019-419

В докладе будут представлены последние достижения в области разработки и исследований непрерывных и импульсных мощных лазерных диодов ближнего ИК диапазона (длины волн от 800 до 1600 нм).

Для разработанных полупроводниковых лазеров на основе систем твердых растворов AlGaInAs/InP, излучающих в условно безопасном для глаз диапазоне длин волн 1400 - 1600 нм, и $\mathrm{AlGaAs} / \mathrm{InGaAs} / \mathrm{GaAs}$ (диапазон длин волн 800-- 1100 нм) будут обсуждаться электрооптические характеристики: выходная оптическая мощность в непрерывном и импульсном (20-100 нс) режимах, КПД, расходимость излучения по быстрой и медленной оси, спектр генерации, температурная чувствительность, температурное сопротивление. Будет дано сравнение характеристик для различных используемых конструкций квантоворазмерных гетероструктур, выращенных методом газофазной эпитаксии из металлорганических соединений: с широким и узким волноводом, барьерными слоями.

Будут обсуждаться подходы для решения задач генерации в лазерных диодах мощных импульсов (десятки ватт) длительностью в диапазоне 0.1-1нс с частотами повторения до 100МГц.

Будут представлены результаты исследований внутренних оптических потерь в зависимости от температуры и тока накачки с использованием метода ввода зондирующего излучения в волновод гетероструктуры работающего лазера. Данные исследования позволяют оптимизировать конструкцию лазерной гетероструктуры для достижения высокой эффективности и оптической мощности, в частности эффекты транспорта носителей заряда через волноводные слои, профили легирования, энергетические барьерные слои и состав волновод. 